\title{
The Caritas and Diaconia Organisations - Providers of Social Services or Secondary Church Structures? Michal Opatrný
}

In his famous inauguration encyclical, Benedict XVI stated that

As the years went by and the Church spread further afield, the exercise of charity became established as one of her essential activities, along with the administration of the sacraments and the proclamation of the word ... The Church cannot neglect the service of charity any more than she can neglect the Sacraments and the Word. ${ }^{1}$

This charitable task is altogether catholic - universal, because it concerns not just the Catholic Church, as if it were a task stipulated by the Pope, but the entirety of Christianity, its very essence. Benedict XVI also thinks in this way when he emphasises the charitable task of Christianity in the encyclical Deus caritas est. Its roots may be found already in the Book of Acts, where practical charity is regarded as one of the key characteristics of the newly forming Church (Acts 2:45-46). At present, the charitable task is being fulfilled across the Christian churches, especially through helping organisations founded by the individual churches or denominations, as well as by local churches, orders, or local Christian bodies such as parishes, congregations or church communities, or they arise as associations of the faithful, etc. ${ }^{2}$ In the European context such organisations are usually accredited as providers of social services, ${ }^{3}$ who receive public funds from the state, regional governments and municipalities, as well as from non-ecclesial foundations and donors. In some cases they are also co-financed from ecclesial resources. The situation has gradually developed since the early $20^{\text {th }}$ century, when denominational helping organisations of approximately the present character started to be established. ${ }^{4}$ Of course, the churches fulfil their charitable task in other ways as well, for example, by hospital chaplaincy, etc. But church-founded helping organisations, in the Czech Republic, for example, Caritas of the Czech Republic (Charita ČR), Diaconia of the Evangelical Church of Czech Brethren (Diakonie ČCE), etc., are dominant, not only in the ecclesial milieu, but among helping organisations in general. That is why, especially in the ecclesial setting, the question is raised whether these organisations still function as a part of the respective church, and are a direct part of its structure, or whether they have already become common providers of social services, or that they function like many other organisations and their connection with the church consists merely in that they have been founded by a church

Deus caritas est 22 .

In the Catholic milieu, cf. CIC 1984, can. 215.

In the Czech Republic, for example, according to Act 108/2006 Coll.

Cf. Catherine MAURER, Wie entstand die „Caritaswissenschaft“?: Ursprung und Entwicklung eines Konzepts und einer Handlungspraxis, in: Die ersten hundert Jahre: Forschungsstand zur Caritas-Geschichte, ed. Michael MANDERSCHEID and Hans-Josef WOLLASCH, Freiburg i. Br.: Lambertus, 1998, p. 144. 
and bear a specific name (for example, Caritas, Diaconia, St. Veronica Hospice, etc.). That is why in this context some authors speak of a so-called dual or binary church structure - one structure is constituted by parishes, congregations or church communities, and the other by local charity organisations, or, in the case of other denominations, by another organisation or a network of organisations. Sometimes such a structure is also called secondary. ${ }^{5}$

It is therefore not surprising that in the course of the 20th century in, for example, the Catholic discourse a whole number of more or less complex conceptions in the sphere of practical theology and the theory of charity (Caritaswissenschaft) emerged, with the intention of reuniting the divided church structure. They always took one of two forms: either they strove to find a way to diaconify the Church - to involve parishes in the activity of Caritas or place a greater emphasis on diakonia in parish pastoral work, or they strove to find a way to re-churchify charity - to return it to the Church and convert Caritas employees to the Christian faith. ${ }^{6}$ According to some authors, such as, for example, Hermann Steinkamp, the greatest obstacle to the reunification of church structure is posed by the church-operated helping organisations themselves, because Christians can delegate their charitable task to them and in that way in a certain sense keep the binary structure alive. ${ }^{7}$ According to this conception, it would principally be best if the charitable task was realised directly by parishes and no church-operated helping organisations existed at all. ${ }^{8}$

But in the present situation it does not seem realistic to expect that these organisations will simply be abolished or become independent and disconnected from the church establishment. Christians would thereby give up on professional approaches to human need by means of social work and other helping professions. Such a solution would therefore be fatal. Conversely, the mere diaconification of parish pastoral work ${ }^{9}$ or the diaconification of churches while maintaining an independent functioning of church-operated helping organisations also appears problematic. Besides the risks associated with developing helping activities without an appropriate rational reflection ${ }^{10}$ - i.e., without knowledge and skills in the field of social work, or without the supervision and control of quality which is customary in the social services sector - such an attitude would also require complex changes of thinking in the churches as well as changes in their structures. ${ }^{11}$ It is therefore necessary to search for a solution which will include the helping organisations and the churches themselves. The intention of such a solution can restrictively be formulated as follows: helping organisations ought not to 'cannibalise' the realisation of the churches' charitable task in parishes, congregations and church communities by pressure on professionalisation; the pastoral structure (i.e., parishes, congregations or church communities) ought not to be limited to divine services, teaching religion and missionary activity. But the intention of a solution which would

5 Cf. Jakub DOLEŽEL, Teoretické ukotvení církevní sociální práce na pozadí obecných a českých charitních dějin až po encykliku Deus caritas est (dissertation thesis, supervisor Heinrich Pompey), Olomouc: CMTF UP, 2011, p. 74; Herbert HASLINGER, Diakonie: Grundlagen für die soziale Arbeit der Kirche, Paderborn - München - Wien - Zürich: Schöningh, 2009, p. 47. Further, cf. Klaus BAUMANN, Unverzichtbar - die Soziale Arbeit der Kirche, Sozialmagazin 12/2007, p. 31; cf. Hermann STEINKAMP, „Zweitstruktur“ - Diakonie oder diakonische Kirche, in: Den Himmel offen halten: Ein Plädoyer für Kirchenentwicklung in Europa, ed. Isidor BAUMGARTNER, Christian FRIESL and András MÁTÉ-TÓTH, Innsbruck - Wien: Tyrolia, 2000, pp. 71-72. Heinrich POMPEY and Paul-Stefan ROSS, Kirche für andere: Handbuch für eine diakonische Praxis, Mainz: Grünewald, 1998, p. 141.

6 Cf. Michal OPATRNÝ and Tereza MORONGOVÁ, Outsourcing blíženecké lásky, Studia theologica 18/2016, pp. 111-124.

7 Cf. Hermann STEINKAMP, „Zweitstruktur“ - Diakonie oder diakonische Kirche, pp. 71-91.

8 Cf. Hermann STEINKAMP, Sozialpastoral, Freiburg i. Br.: Lambertus, 1991, p. 158.

9 At the Faculty of Theology of the University of South Bohemia a dissertation project is at present being realised on the topic of parish charity (not only parish charities as part of a diocesan charity), which after a preliminary investigation in the pastoral practice must grapple with the fundamental difficulty that there is virtually no charitable involvement of parishes in the Czech Republic. The project is being carried out by Monika Flídrová.

10 Cf. Silvia STAUB-BERNASCONI, Soziale Arbeit als Handlungswissenschaft, Bern - Stuttgart - Wien: Haupt, 2007, p. 12.

11 Cf. Michal OPATRNÝ and Tereza MORONGOVÁ, Outsourcing blíženecké lásky, pp. 123-124. 
include the helping organisations and the pastoral structures of churches can also be formulated in a supporting way. According to such a conception, helping organisations ought to support the charitable task of the church within its pastoral structure and that should in turn support the organisations in their activity, thereby enabling them to be not merely providers of social services, but organisations realising first of all the church's charitable task.

That is why in this study I want to focus on such a supporting conception of the relationship between the charitable and pastoral structure of churches. My primary aim is to analyse and critically evaluate the above-described situation of the binary structure of churches from a theological point of view. ${ }^{12}$ I want to propose solutions for practice only in the minimum necessary measure, because the willingness to change existing practice is to a great extent conditioned by accepting the analysis of the practice as being insufficient.

\section{Origin and development of the binary structure}

A number of years ago, Norbert Mette presented his interpretation of the history of Christian charitable and diaconic activity, with which he attempted to explain especially the state of the contemporary structure of a church divided, for example, in the Catholic milieu, between parishes and the Caritas organisation. ${ }^{13} \mathrm{He}$ finds its roots in the $2^{\text {nd }}$ century $\mathrm{AD}$, when there was a certain rivalry between priests (presbyters) and deacons, which resulted in the reduction of deaconship to a preparatory step to priesthood. That, however, brought along a loss of institutional responsibility for the Church's charitable task, accompanied by a loss of awareness of the 'universal deaconship of the faithful', i.e., at the same time a loss of awareness of the significance of the church's charitable task. In subsequent centuries the growing importance of the cultic dimension of divine service, which was to do with the emphasis placed on the priestly office, conditioned the parallel devaluation of the social dimension of divine service and eventually lead up to a situation labelled by Mette as the social disintegration of the cult. That brought along a tendency to separate the ecclesial community and charity to the extent that charity gradually came to be performed by religious orders and communities set up for that purpose. And although initiatives reacting 'bottom-up' to the situational changes of need in society arose time and again, they were either 'dispossessed' by means of pressure on their (officially-)ecclesial acknowledgment, or they were forced, so to speak, to go into 'secularisation.' ${ }^{14}$

So, according to Norbert Mette, in complex modern society a differentiated organisational form of Caritas as a non-profit organisation accredited as a provider of social services is ultimately inevitable. But, as a result, Caritas is accompanied by a 'loss of communion (koinonia)' - diakonia is not the task of the community of Christians; the Christian community is not responsible for Christian diakonia. So, according to Mette, charity has become secondary (subordinate) for Christian action, not constitutive of it. ${ }^{15}$ As already mentioned, in the course of the $20^{\text {th }}$ century, when modern charitable organisations of churches were being constituted, a number of attempts were made to span the abyss between the Christian community - koinonia and its

12 Cf. Herbert HASLINGER et al., Zu Selbstverständniss und Konzept dieser Praktischen Theologie, in: Handbuch Praktische Theologie: Grundlegungen, ed. Herbert HASLINGER, Mainz: Grünewald, 1999, pp. 31-32.

13 Cf. Norbert METTE, Theologie der Caritas, in: Grundkurs Caritas, ed. Markus LEHNER and Wilhelm ZAUNER, Linz: Landesverlag, 1993, pp. 125-127.

14 In this context, Sheldrake speaks, for example, of the Beguine movement, but also of the Society of Jesus itself (cf. Philip SHELDRAKE, Spiritualita a historie: Úvod do studia dějin a interpretace krestanského duchovního života, Brno: CDK, 2003, especially pp. 132-155, or pp. 129-131).

15 Cf. Norbert METTE, Theologie der Caritas, p. 126. 
charitable task - diakonia. In practice, all of these attempts failed to some extent or were never really implemented in practice. ${ }^{16}$

An important impulse for re-opening this issue was the election of Cardinal Jorge Mario Bergoglio to the papal office in 2013. By assuming the name Francis he gave his pontificate a significantly charitable dimension. ${ }^{17}$ Although Francis of Assisi is not primarily associated in Catholic hagiography with charity, the name very well renders the intention of Francis' pontificate that constitutional of Christianity is a conception of humility stemming from respect for others and for the whole of creation. ${ }^{18}$ Precisely, the constitutive connection between the faith and a way of life, or the interconnection of contents of faith and charity, ${ }^{19}$ which is sometimes expressed with the slogan 'a poor church - a church for the poor ${ }^{20}$, is also a new impulse for uniting the divided ecclesial structure. For unless the relationship between the content of the Christian faith and practical charity is regarded as mutually constitutive, it will hardly be able to reunite the divided ecclesial structure. A pastoral structure explicitly expressing the content of the faith by means of words and symbolic action will not need Caritas any more than it does now. ${ }^{21}$ And Caritas in the organised form of a helping organisation providing social services will still focus on those social services that are well paid by the social state; and less or not at all on activities rigorously realising the charitable task of Christians. ${ }^{22}$

\section{Binary structure mentality}

However, the binary structure has already been appropriated by both the Catholic Church and Caritas. So, the required change is not being blocked so much by the helping organisations alone, or the Church alone, but the notion that the doubled structure is in fact normal - a binary structure mentality. That has altogether practical consequences:

- Caritas is commonly perceived by clients, donors, state, regional and municipal officials, and sometimes even by its own employees, just as any other provider of social services. If they are aware of its ecclesial origin at all, they perceive it as a 'filial company' of the Church of sorts - an organisation which is established by the Church, which is personally and legally interconnected with it in some way, but which is not identical with the Church, whether at first or at second glance: it resides in different buildings and people encounter it in a context different from the one in which they encounter the Church.

16 Cf. Michael MANDERSCHEID and Hannes KRAMER, Programatik und Praxis von Gemeindeorientierung des Caritasverbandes Erfahrung und Aporie, in: Zwischen versorgter Gemeinde und entsorgender Sozialarbeit: Dokumentation des Symposions „Christliche Diakonie zwischen System und Lebenswelten“von 13. bis 15. März 1989, ed. Michael MANDERSCHEID, Freiburg i. Br.: DCV, 1990, pp. $8-11$.

17 Cf. Paul M. ZULEHNER, Kirchenentwicklung braucht Visionen: Papst Franziskus liefert uns solche, in: Papst Franziskus: Ermutigung und Herausforderung für Theologie und Pastoral in Mittel- und Osteuropa, Pastoraltheologische Hefte 8 (2015): Eine Veröffentlichung des Post-Netzwerkes der mittel- und osteuropäischen Pastoraltheologinnen und Pastoraltheologen, ed. Mieczysław POLAK, Gniezno - Wien: Gaudentinum, 2015, p. 13.

18 Cf. Wiesław PRZYGODA, Armut als Pastorales Prinzip nach Papst Franziskus, in: Papst Franziskus: Ermutigung und Herausforderung für Theologie und Pastoral in Mittel- und Osteuropa, Pastoraltheologische Hefte 8 (2015): Eine Veröffentlichung des Post-Netzwerkes der mittel- und osteuropäischen Pastoraltheologinnen und Pastoraltheologen, ed. Mieczysław POLAK, Gniezno - Wien: Gaudentinum, 2015, pp. 59-63.

19 Cf. Josip BALOBAN, Papst Franziskus und die müden europäischen Verkündiger und Christen, in: Papst Franziskus: Ermutigung und Herausforderung für Theologie und Pastoral in Mittel- und Osteuropa, Pastoraltheologische Hefte 8 (2015): Eine Veröffentlichung des Post-Netzwerkes der mittel- und osteuropäischen Pastoraltheologinnen und Pastoraltheologen, ed. Mieczysław POLAK, Gniezno - Wien: Gaudentinum, 2015, pp. 29-30.

20 Evangelii gaudium 198.

21 Cf. Jakub DOLEŽEL, Farní charity: dozvuky encykliky Deus caritas est a pravděpodobný stav moravských farností, Studia theologica 3/2016, pp. 147-166.

22 Cf. Michal OPATRNÝ and Tereza MORONGOVÁ, Outsourcing bliženecké lásky, pp. 111-124. 
- The representatives of the churches, Caritas management and some of its churched employees, volunteers or clients, on the other hand, perceive primarily the theological unity of Caritas and the Church - that the organisation fulfils the charitable task mentioned above, which according to Benedict XVI the Church must not neglect.

These two ways of understanding Caritas can ultimately be so widely different that they give rise to deep misunderstandings and grave conflicts. Succinctly expressed, '... while an external observer describes the situation as it is, the Catholic Church describes the identity [of Caritas], as it ought to be.23 But the latter view completely overlooks the fact that a part of the Church is not concerned with the activity of Caritas at all. In fact it is logical, because in this conception it need not be concerned with it at all. It is therefore also possible to say that empirically (i.e., based on the observable facts) Caritas is perceived as a provider of social services set up by a Christian organisation, while theologically - and solely theologically - it also perceives itself as a part of the Church fulfilling one of its important tasks.

The tension between the concepts empirically and theologically also describes and explains different types of conceptions of the Church and its relationship to the world, or to society:

- The first type is characterised by identifying the empirical and theological reality of the Church, which means that what theology, or ecclesiology, says of the Church is understood as a description of the present form of the empirical Church. ${ }^{24}$

- In the second type, the theological and empirical reality of the Church is strictly separated. Not only non-Christians and unchurched 'register' Christians, but also many practising lay persons perceive the Church as one of many specialised institutions, namely as an institution specialised in satisfying religious needs. Only those who are appointed to pastoral work and have undertaken theological studies, and some very few active lay faithful educated in the content of faith, perceive the theological meaning of the words Church, People of God, Body of Christ, etc.

- The third type, shown by the author of this distinction Medard Kehl to be the only justified one, is the unity of both realities in a sacramental manner. This is also the view of the Second Vatican Council, namely of the first article of the dogmatic constitution on the Church Lumen gentium: '... for the external visible form of the Church ought to be a sign, a symbol and a sacrament, a means and instrument of the internal mystery of the Church. ${ }^{25}$ When this third type is applied to the tension between the empirical and theological understanding of Caritas, we must ask not only how the external - empirical - form of Caritas ought to be changed in order to express its theological conception, but also what is the nature of the Church, its internal ordering and orientation, and therefore whether there is something in the Church for Caritas to refer to.

The fact that Caritas organisations are perceived as mere providers of social services, not only by the general society, but also within the Church itself, is a symptom of the little attention devoted in the Church to social issues and problems. Expressed differently, it is a symptom of the fact that the ecclesial structure is not only dual or binary, but divided into the primary pastoral structure and the secondary - subordinate - charitable structure.

23 Cf. Petr KOLAŘíK, Identita sociálních služeb poskytovaných katolickou církví, Sociální práce / Sociálna práca 4/2008, pp. 76 and 82.

24 Such a conception can be encountered in older textbooks, which had been used to teach ecclesiology in the Czech Republic up to the 1990s. A consequence of such a view is the fatal error of identifying the concepts of the Church and the Kingdom of God. Cf. Vojtěch NOVOTNÝ, Česká katolická eklesiologie na počátku druhé poloviny 20. století, in: Česká katolická eklesiologie druhé poloviny 20. století, ed. Vojtěch NOVOTNÝ, Praha: Karolinum, 2007, pp. 9-46.

25 Cf. Medard KEHL, Kam kráčí církev: Diagnóza doby, Brno: CDK, 2000, pp. 45-51. 


\section{Conclusion}

If we therefore want to search for a supporting conception of the cooperation between the helping organisation and the pastoral structure of a church operating it in the realisation of the charitable task of Christianity, it is first of all necessary to return its true value to the Christians' charitable task. As already mentioned in the introduction and in point 1, in the Catholic context precisely that is one of the intentions of the pontificate of the present Roman bishop Francis, albeit the topic had already been opened up by his predecessor Benedict XVI. That brings along the issue of the proprium of Christian charity, viz. the question of what priorities ought to be pursued in fulfilling the charitable task. For the charitable task seems to have been to a great extent defamed by being dispersed into an, at first glance, infinite number of charitable activities realised by Christian helping organisations. Charity conceived in this way ultimately does not significantly differ from other charitable activities and all differences and distinct priorities become indecipherable. The traditionally and biblically not only grounded, but especially justified, proprium of charity work is helping those who are not helped by others. That is the unambiguous conclusion following from the parable of the Good Samaritan, where a heretic and a schismatic becomes a neighbour when he does not hesitate to help one whom others have passed by unattended. As the whole parable along with its context explains, the one who is a neighbour to others does what is important for salvation. ${ }^{26}$

However, at present, church-operated helping organisations focus on social services which are favoured by the state or the political regions. ${ }^{27}$ They therefore need to make changes in their priorities and structure, which will enable them to attend to clients for whom the social system of the state and society as a whole does not provide, or provides but little and non-systemically. Thereby they will also become easier to grasp and decipher for the churches operating them. Naturally, such a change will bring along financial instability, because the organisation will not be able to (fully) rely on support from the state and its social services system. In order to realise and maintain such a change in the orientation of their basic activity, the Caritas and Diaconia organisations will need significant support and help from their churches. Such support may be financial (revenues from restitutions, offerings), material (harvest, offerings) or also personal (volunteers). Providing support in such a scope cannot be in the powers of the church headquarters alone, but will need to be appropriated by the particular cells of the church's pastoral structure - parishes, congregations, or church communities. In that way, the Caritas and Diaconia organisations will support the realisation of the charitable task or the church within its pastoral structure and the churches will empower their organisations to stop being mere providers of social services.

26 Cf. Michal OPATRNÝ, Podobenství o milosrdném Samaritánovi a proprium křestanské charitativní práce v kontextu tzv. teorie charity, Studia theologica 3/2016, pp. 167-184.

27 Cf. Michal OPATRNÝ and Tereza MORONGOVÁ, Strukturálně-kritická sociální práce v církevním hávu: Contradictio in adjecto?, in: Sociální práce v nejisté době, ed. Ondřej ŠTĚCH, Peter PATYI and Zuzana TRUHLÁŘOVÁ, Hradec Králové: Gaudeamus, 2016, pp. $38-41$. 


\title{
The Caritas and Diaconia Organisations - Providers of Social Services or Secondary Church Structures?
}

\begin{abstract}
The study deals with the relationship between church-operated helping organisations and the churches operating them. It starts from the general charitable task of Christians, which is at present being realised precisely by church-operated helping organisations accredited as providers of social services. The study shows how the churches' charitable task is impeded by such a practice. It identifies the different perception of the organisations and their work in the ecclesial and secular milieu as the cause of the situation. The secular setting does not understand the charitable organisations as a part of the church which realises its charitable task through them, but rather as the church's filial company. As a result, the organisations' work is perceived in the ecclesial environment as the work of a common provider of social services, which raises the question of whether they are still Christian. The study therefore proposes a basic direction for solving the relationship of helping organisations and the churches operating them, so that the organisations partially give up on being integrated into the system of social services in order to help those for whom the social services system does not provide. For that they need substantial material and moral support on the part of the churches. If the churches provided it, the responsibility for realising the charitable task would thereby be relocated to their basic structure.
\end{abstract}

Keywords: charity, diakonia, Caritas, church, Christian social work, social work, ecclesiology

\section{Author contact}

Assoc. Prof. Michal Opatrný, Dr. theol.

University of South Bohemia in České Budějovice

Faculty of Theology, Department of Ethics, Psychology and Charitable Work

Kněžská 8, 37001 České Budějovice

mopatrny@tf.jcu.cz 